\title{
EDITORIAL
}

\section{RBCE: AVANÇOS, POSSIBILIDADES, PERSPECTIVAS}

Depois de muitos anos com três edições anuais, a Revista Brasileira de $\mathrm{Ci}$ ências do Esporte alcança uma marca que consideramos bastante significativa, ao se estabelecer, pelo segundo ano, de forma trimestral. Em movimento que não permite retrocesso, esse patamar se consolida, ao mesmo tempo em que novos desafios para a revista e para a comunidade da Educação Física/Ciências do Esporte se renovam.

Um desses desafios diz respeito às estratégias de financiamento. Malgrado o fundamental apoio que temos tido do Ministério do Esporte e os recursos do próprio Colégio Brasileiro de Ciências do Esporte, precisamos desenvolver estratégias coletivas de manutenção e incremento de nossas revistas científicas em longo prazo. Como sempre lembramos, os periódicos e sua boa saúde são fundamentais para a sustentação da área de conhecimento, de seus programas de pós-graduação, de seus pesquisadores.

Não estamos solitários nessa tarefa. Além dos autores e revisores, contamos com nosso Conselho Editorial. A partir deste número ele está sobremaneira reforçado. Damos boas vindas e esperamos uma estreita colaboração com eles. Marcus Aurélio Taborda de Oliveira, da Universidade Federal de Minas Gerais, que já atuou como editor da RBCE (com grande contribuição à História da Educação do Corpo no Brasil), é um deles. Paulo de Tarso Veras Farinatti, das Universidades Estadual do Rio de Janeiro e Salgado de Oliveira, por dois mandatos um dos representantes de área junto ao CNPq (e dos mais importantes pesquisadores brasileiros no que se costuma chamar de Biodinâmica do Exercício Físico), é outro novo membro. A eles se juntam Silvana Vilodre Goellner, da Universidade Federal do Rio Grande do Sul, uma das mais importantes pesquisadoras brasileiras nos Estudos de Gênero (também com história de atuação como editora da RBCE), e Ricardo Luis Crisorio, da Universidad Nacional de La Plata, Argentina, renomado pesquisador dos campos 
da Filosofia e da Pedagogia das práticas corporais. Reforços de muito peso para a nossa revista.

Os artigos originais do presente número dedicam-se ao esporte em várias de suas dimensões, a outras práticas corporais, à formação de professores, ao corpo e às formas de interpretá-lo. Dois artigos de revisão e uma resenha completam este número.

Boa leitura!

Florianópolis, Vitória, outubro de 2011 .

Alexandre Fernandez Vaz

Jaison José Bassani

Felipe Quintão de Almeida 